


\title{
JOB STRESS AMONG POLICE OFFICERS IN MANSOURA CITY, EGYPT
}

\author{
By \\ ${ }^{1}$ Abou-ElWafa HS, ${ }^{1}$ El-Gilany A and ${ }^{2}$ Rashed IH \\ ${ }^{1}$ Department of Public Health and Community Medicine, ${ }^{2}$ Department of Psychiatry, Faculty of Medicine, \\ Mansoura University, Mansoura, Egypt.
}

\begin{abstract}
Introduction: Police officers experience frequent and ongoing stressors in their work. Exposure to violence, suffering, and death is inherent to their profession. Aim of work: To describe the level of job stress, risk factors, and coping strategies adopted to reduce it in police officers in Mansoura city, Egypt. Materials and methods: Police officers completed a self-administered questionnaire covering the socioeconomic and occupational data, occupational stress index scale and coping inventory for stressful situations. Results: A high average total Occupational Stress Index (OSI) score (133.7) was found with role overload having the highest subscale mean (20.9). The significant factors associated with level of stress were rank of officers, nature and sector of work, shift work, smoking and other habits. Coping strategies to overcome stress were mainly task-oriented. Conclusion: Pre-employment and periodic medical examination and psychological assessment of officers is required together with implementation of stress management program and counseling. Further large scale multicenter research is recommended.
\end{abstract}

Key words: Police officers, Job stress, Occupational exposure, Coping, Workplace and mental health 


\section{Introduction}

There is an increasing concern with stress within the workplace (Collin and Gibbs, 2003). Stress in various occupations differs according to the nature of work and its influencing factors (Czaja-Miturai et al., 2013).

Research has implicated job stress as an important causal agent in health problems such as coronary heart disease, gastro-intestinal malfunction, dermatological problems, severe nervous conditions, insomnia, and increased levels of destructive stress hormones, post-traumatic stress disorder suicide and other physical problems (Ramachandruni et al., 2004; Kivimak et al., 2006; Matthews et al., 2006; Violanti et al., 2006; Wang et al., 2007).

Perhaps one of the most stress prone occupations is that of police profession. Because police not only acts as a law enforcing agency but also as an instrument of social service, an agent of social change and the protector of the rights and duties of people. Police personnel are often involved in dealing with criminals, very important person's (VIP's) security duties, outdated laws and collapse of other agencies of criminal justice system (Ranta, 2009).

Police personnel of different ranks differ both quantitatively and qualitatively in their experience of stress. The subordinate officers had the highest scores on stressors such as job boredom, quantitative work overload and lack of praise and relatively high scores on noxious physical environment, communication quality, decision latitude and role ambiguity (Mathur, 1999).

The stressed police officers pose a threat to themselves, their colleagues, offenders and/or to public safety and thus it is a matter of urgent concern for psychologists in particular and mental health researchers in general (Ranta, 2009).

To the best authors' knowledge no past studies have investigated job stress among police officers in Egypt especially after revolutions (2011 \& 2013) where "To date" the security situation across the country was to some extent collapsed and lacking which increased physical and psychological burdens on police officers to handle the situation. 


\section{Aim of work}

To describe the level of job stress, risk factors, and coping strategies adopted to reduce it in police officers in Mansoura city, Egypt.

\section{Materials and methods}

- Study design: A descriptive crosssectional study was carried out upon police officers at Mansoura city.

- Place and duration of study: The study was carried out upon police officers at Mansoura city during the period from October 1, 2015 to December 31, 2015.

- Study sample: was calculated online (https://www.dssresearch. c o m / K n ow ledge Center/ t o o l k i t c l c u 1 a tors/ samplesizecalulators.aspx). pilot study, carried out on 10 policemen (not included in the full-scale study), revealed that the mean occupational stress index $(\mathrm{OSI})=135.2$ with $\mathrm{SD}=12.0$. With alpha error $=5 \%$, study power $=80 \%$ and $3 \%$ precision, then the sample size was estimated to be 99 at least.

\section{-Study methods:}

A questionnaire was distributed to 116 police officers who fulfilled the eligibility criteria (exclusion of those with psychiatric disorders or less than one year of employment) and agreed to participate in the study. A total of 100 completed questionnaires were returned. So, the response rate was $86.2 \%$.

Each participant completed a self-administered Arabic-translated questionnaire after explanation of how to answer the questionnaire and responding to any inquiries by one of the investigators. Each questionnaire required 15-20 min to be completed.

Police officers were recruited consequently until the required sample size was completed at their social club where time allowed for.

The questionnaire included; socio-demographic characteristics, work profile, and job stress using the Occupational Stress Index (OSI) (Srivastava and Singh, 1981) which consists of 46 items, each to be rated on the five point scale. Out of 46 items; 28 are 'True - Keyed' and 18 are 'False - 
Keyed'. The items relate to almost all relevant components of the job which cause stress in some way or the other, such as, role overload, role ambiguity, role conflict, unreasonable group and political pressure, responsibility for persons, under participation, powerlessness, poor peer relations, intrinsic impoverishment, low status, strenuous working conditions and unprofitability. Coping was assessed using Arabic version of Coping Inventory for Stressful Situations comprised 21 questions adult version (CISS 21) (Endler and Parker, 1999).

The questionnaire was forward translated into Arabic by two translators with Arabic as the first language and English as the second language. The two Arabic versions were compared and a consensus was made about any controversies in the translations.

\section{Consent}

Approval of the Institutional Review Board (IRB) was obtained.

\section{Ethical Approval}

An informed verbal consent of study subjects, to participate voluntarily in the study with a full right to withdraw, was obtained with assurance of confidentiality and anonymity of the data.

\section{Data management}

Data were entered and statistically analyzed using the Statistical Package for Social Sciences (SPSS) version 17. Qualitative data were described as numbers and percentages. Chi-square $(\chi 2)$ test was used for comparison between groups. Quantitative data were described as means and standard deviation. Pearson's correlation was used to describe the relation between the 12 subscales of OSI. Independent t-test and one way ANOVA with LSD post-hoc multiple comparisons were used for comparison between groups, as appropriate. "p value $\leq 0.05$ " was considered to be statistically significant 


\section{Results}

Table (1) : Descriptive statistics of the subscales of Occupational Stress Index (OSI) in policemen.

\begin{tabular}{|c|l|c|c|c|c|c|}
\hline $\begin{array}{c}\text { Serial } \\
\text { No. }\end{array}$ & \multicolumn{1}{|c|}{ Subscale } & Codes & Mean & SD & Min & Max \\
\hline $\mathbf{1}$ & Role overload & RO & 20.9 & 2.8 & 16 & 27 \\
\hline $\mathbf{2}$ & Role ambiguity & RA & 10.8 & 1.8 & 6 & 15 \\
\hline $\mathbf{3}$ & Role conflict & RC & 15.5 & 2.04 & 10 & 21 \\
\hline $\mathbf{4}$ & $\begin{array}{l}\text { Unreasonable group and } \\
\text { political pressure }\end{array}$ & UGPP & 11 & 1.7 & 7 & 15 \\
\hline $\mathbf{5}$ & Responsibility for persons & RP & 9.8 & 1.6 & 6 & 15 \\
\hline $\mathbf{6}$ & Under participation & UP & 11.7 & 3.04 & 6 & 19 \\
\hline $\mathbf{7}$ & Powerlessness & PL & 8.7 & 2.04 & 3 & 14 \\
\hline $\mathbf{8}$ & Poor peer relations & PPR & 8.9 & 2.1 & 4 & 14 \\
\hline $\mathbf{9}$ & Intrinsic impoverishment & II & 10.1 & 2.5 & 5 & 16 \\
\hline $\mathbf{1 0}$ & Low status & LS & 6.2 & 2.03 & 3 & 12 \\
\hline $\mathbf{1 1}$ & Strenuous working conditions & SWC & 13.2 & 2.8 & 7 & 20 \\
\hline $\mathbf{1 2}$ & Unprofitability & UF & 6.9 & 1.4 & 3 & 10 \\
\hline $\begin{array}{c}\text { Overall } \\
\text { indess }\end{array}$ & & & 133.7 & 15.3 & 103 & 180 \\
\hline
\end{tabular}

Table (1) : shows that among the minimum scores, Powerlessness, Low status, and Unprofitability scored least (3) followed by Poor peer relations scoring (4) and the highest score was (16) for Role overload. When the maximum scores were compared, the highest score of (27) was for Role overload and the least score of (10) was for Unprofitability. The average score was highest for Role overload (20.9) and the least was for Low status with mean (6.2). The overall stress index had a mean score $(133.7 \pm 15.3)$ with a minimum score (103) and a maximum score (180). 
Table (2) : Variation of total OSI score with possible sources of stress in policemen.

\begin{tabular}{|c|c|c|c|}
\hline Source of stress & $\mathbf{N}(\mathbf{1 0 0})$ & $\begin{array}{c}\text { Total OSI score } \\
(\text { Mean } \pm \text { SD }) \\
\end{array}$ & Test of significance \\
\hline $\begin{array}{l}\text { Age in years }(\text { mean } \pm S D) \\
\text { Less than } 30 \\
30-40 \\
\text { More than } 40 \\
\end{array}$ & $\begin{array}{l}33.4 \pm 7.1 \\
35(35.0) \\
43(43.0) \\
22(22.0) \\
\end{array}$ & $\begin{array}{l}133.8 \pm 14.6 \\
134.7 \pm 16.4 \\
131.6 \pm 14.9 \\
\end{array}$ & $\begin{array}{l}\mathrm{f}=0.3 \\
\mathrm{p}>0.05\end{array}$ \\
\hline $\begin{array}{l}\text { Residence } \\
\text { Rural } \\
\text { Urban } \\
\end{array}$ & $\begin{array}{l}19(19.0) \\
81(81.0) \\
\end{array}$ & $\begin{array}{c}137.6 \pm 17 \\
132.8 \pm 14.9 \\
\end{array}$ & $\begin{array}{l}\mathrm{t}=1.2 \\
\mathrm{p}>0.05\end{array}$ \\
\hline $\begin{array}{l}\text { Marital status } \\
\text { Single } \\
\text { Married }\end{array}$ & $\begin{array}{l}28(28.0) \\
72(72.0) \\
\end{array}$ & $\begin{array}{l}136.4 \pm 11.4 \\
132.7 \pm 16.6 \\
\end{array}$ & $\begin{array}{l}t=1.1 \\
p>0.05\end{array}$ \\
\hline $\begin{array}{l}\text { Income } \\
\text { Able to save } \\
\text { Just enough }\end{array}$ & $\begin{array}{l}60(60.0) \\
40(40.0) \\
\end{array}$ & $\begin{array}{c}131.8 \pm 11.3 \\
135 \pm 17.5 \\
\end{array}$ & $\begin{array}{l}\mathrm{t}=1.04 \\
\mathrm{p}>0.05\end{array}$ \\
\hline $\begin{array}{l}\text { Experience years [median (min - } \\
\text { max)] } \\
\text { Less than } 11 \\
\text { More than } 11\end{array}$ & $\begin{array}{c}11(2-31) \\
58(58.0) \\
42(42.0)\end{array}$ & $\begin{array}{c}133 \pm 13.3 \\
134.8 \pm 17.9\end{array}$ & $\begin{array}{l}\mathrm{t}=0.6 \\
\mathrm{p}>0.05\end{array}$ \\
\hline $\begin{array}{l}\text { Rank among police force } \\
\text { Lieutenant } \\
\text { Captain } \\
\text { Major } \\
\text { Lieutenant colonel and Colonel } \\
\text { Brigadier and Major general } \\
\end{array}$ & $\begin{array}{l}15(15.0) \\
40(40.0) \\
27(27.0) \\
11(11.0) \\
7(7.0) \\
\end{array}$ & $\begin{array}{c}130.1 \pm 9.2^{\mathrm{a}} \\
133.3 \pm 14.7^{\mathrm{b}} \\
139.6 \pm 17.3^{\mathrm{ac}} \\
134.9 \pm 16.9^{\mathrm{d}} \\
119.6 \pm 9.5^{\mathrm{bcd}}\end{array}$ & $\begin{array}{c}\mathrm{f}=2.9 \\
\mathrm{p}<0.05^{*}\end{array}$ \\
\hline $\begin{array}{l}\text { Place of work } \\
\text { Urban } \\
\text { Rural }\end{array}$ & $\begin{array}{c}91(91.0) \\
9(9.0) \\
\end{array}$ & $\begin{array}{l}133.1 \pm 15.2 \\
139.7 \pm 16.8 \\
\end{array}$ & $\begin{array}{l}\mathrm{t}=1.2 \\
\mathrm{p}=0.2\end{array}$ \\
\hline $\begin{array}{l}\text { Nature of work } \\
\text { Office } \\
\text { Field } \\
\text { Both } \\
\end{array}$ & $\begin{array}{c}49(49.0) \\
45(45.0) \\
6(6.0) \\
\end{array}$ & $\begin{array}{l}133.5 \pm 15.5^{\mathrm{a}} \\
135.9 \pm 15.1^{\mathrm{b}} \\
119.5 \pm 5.8^{\mathrm{ab}}\end{array}$ & $\begin{array}{c}\mathrm{f}=3.2 \\
\mathrm{p}<0.05^{*}\end{array}$ \\
\hline $\begin{array}{l}\text { Sector of work } \\
\text { Traffic } \\
\text { Police station } \\
\text { Civil defence } \\
\end{array}$ & $\begin{array}{c}35(35.0) \\
61(61.0) \\
4(4.0) \\
\end{array}$ & $\begin{array}{c}131.4 \pm 14.6^{\mathrm{b}} \\
133.8 \pm 14^{\mathrm{a}} \\
153.8 \pm 28.5^{\mathrm{ba}} \\
\end{array}$ & $\begin{array}{c}\mathrm{f}=4.1 \\
\mathrm{p}<0.05^{*}\end{array}$ \\
\hline
\end{tabular}




\begin{tabular}{|l|c|c|c|}
\hline Shift work & & & $\mathrm{t}=5.2$ \\
Yes & $38(38.0)$ & $142.8 \pm 15.1$ & $\mathrm{p}<0.001^{*}$ \\
No & $62(62.0)$ & $128.2 \pm 12.7$ & $\mathrm{t}=1.8$ \\
\hline Enjoy usual vacations & $48(48.0)$ & $130.8 \pm 13.7$ & $\mathrm{p}>0.05$ \\
Yes & $52(52.0)$ & $136.4 \pm 16.4$ & $\mathrm{f}=5.8$ \\
No & & & $\mathrm{p}<0.05^{*}$ \\
\hline Smoking & $47(47.0)$ & $138.6 \pm 13.9^{\mathrm{a}}$ & \\
Current smoker & $20(20.0)$ & $132.8 \pm 18.3$ & \\
X-smoker & $33(33.0)$ & $127.3 \pm 13.1^{\mathrm{a}}$ & \\
Never smoker & & & $\mathrm{t}=3.9$ \\
\hline Other habits & & $\mathrm{p}<0.001^{*}$ \\
Yes & & \\
No & & \\
$6(6.0)$ & & \\
$94(94.0)$ & & \\
$155.7 \pm 15.1$ & & \\
$132.3 \pm 14.3$ & & & \\
\hline
\end{tabular}

$\mathrm{a}, \mathrm{b}, \mathrm{c} \& \mathrm{~d}$ : significant differences between the corresponding groups using LSD post hoc multiple comparison
\# : e.g. Hashish, cannabis, tramadol
*: Significant

Table (2) : shows that the mean age of the study group was 33.4 years $( \pm 7.1)$ with the majority between 30 - 40 years who had the highest mean OSI score with statistically non-significant difference across age groups. The majority of them were urban residents and work in urban areas (91\%) with statistically non-significant lower mean OSI scores. Most of the studied policemen were married (72\%) with an income described as being able to save (60\%) with working experience of less than 11 years $(58 \%)$.

The rank "major" had the highest mean OSI with statistically significant difference across ranks. About half of them (49\%) had office work with significantly lower mean OSI score than those with field work. About $60 \%$ of the studied policemen belonged to police stations while the highest average OSI score was amongst civil defense sector with statistically significant difference between them. Policemen who work in shifts and those who are current smokers and those with special habits had statistically significant higher mean OSI scores. 
Abou-ElWafa HS, et al.,

Table (3) : Coping strategies among policemen

\begin{tabular}{|c|c|c|c|c|c|c|}
\hline \multirow[t]{2}{*}{ Subscale } & $\begin{array}{c}\text { Not at } \\
\text { all }\end{array}$ & Rarely & Sometimes & Always & $\begin{array}{l}\text { Very } \\
\text { much }\end{array}$ & \multirow{2}{*}{$\begin{array}{l}\text { Mean } \pm \text { SD } \\
\text { (Median) }\end{array}$} \\
\hline & $\mathbf{N}(\%)$ & $\mathbf{N}(\%)$ & $\mathbf{N}(\%)$ & $\mathbf{N}(\%)$ & $\mathbf{N}(\%)$ & \\
\hline \multicolumn{7}{|l|}{ Task-oriented coping } \\
\hline $\begin{array}{l}\text { Focus on the } \\
\text { problem and see } \\
\text { how I can solve it }\end{array}$ & $0(0.0)$ & $6(6.0)$ & $23(23.0)$ & $43(43.0)$ & $28(28.0)$ & $3.9 \pm 0.9(4)$ \\
\hline $\begin{array}{l}\text { Think about how } \\
\text { I solved similar } \\
\text { problems }\end{array}$ & $0(0.0)$ & $5(5.0)$ & $51(51.0)$ & $36(36.0)$ & $8(8.0)$ & $3.5 \pm 0.7(3)$ \\
\hline $\begin{array}{l}\text { Determine a course } \\
\text { of action and follow } \\
\text { it }\end{array}$ & $1(1.0)$ & $3(3.0)$ & $28(28.0)$ & $44(44.0)$ & $24(24.0)$ & $3.9 \pm 0.8$ \\
\hline $\begin{array}{l}\text { Work to understand } \\
\text { the situation }\end{array}$ & $0(0.0)$ & $4(4.0)$ & $21(21.0)$ & $46(46.0)$ & $29(29.0)$ & $4 \pm 0.8(4)$ \\
\hline $\begin{array}{l}\text { Take corrective } \\
\text { action immediately }\end{array}$ & $3(3.0)$ & $29(29.0)$ & $14(14.0)$ & $47(47.0)$ & $7(7.0)$ & $3.3 \pm 1.1(4)$ \\
\hline $\begin{array}{l}\text { Think about the } \\
\text { event and learn } \\
\text { from my mistakes }\end{array}$ & $0(0.0)$ & $6(6.0)$ & $31(31.0)$ & $34(34.0)$ & $29(29.0)$ & $3.9 \pm 0.9(4)$ \\
\hline $\begin{array}{lr}\text { Analyze } & \text { my } \\
\text { problem } & \text { before } \\
\text { reacting } & \\
\end{array}$ & $0(0.0)$ & $5(5.0)$ & $26(26.0)$ & $24(24.0)$ & $45(45.0)$ & $4.1 \pm 1(4)$ \\
\hline Total & & & & & & $26.5 \pm 2.9(26)$ \\
\hline \multicolumn{7}{|l|}{$\begin{array}{l}\text { Emotion-oriented } \\
\text { coping }\end{array}$} \\
\hline $\begin{array}{l}\text { Blame myself for } \\
\text { having gotten into } \\
\text { this situation }\end{array}$ & $6(6.0)$ & $29(29.0)$ & $22(22.0)$ & $33(33.0)$ & $10(10.0)$ & $3.1 \pm 1.1(3)$ \\
\hline $\begin{array}{l}\text { Feel anxious about } \\
\text { not being able to } \\
\text { cope }\end{array}$ & $15(15.0)$ & $22(22.0)$ & $25(25.0)$ & $29(29.0)$ & $9(9.0)$ & $3 \pm 1.2(3)$ \\
\hline $\begin{array}{l}\text { Blame myself for } \\
\text { being too emotional } \\
\text { about the situation }\end{array}$ & $3(3.0)$ & $14(14.0)$ & $39(39.0)$ & $33(33.0)$ & $11(11.0)$ & $3.4 \pm 0.9(3)$ \\
\hline Become very upset & $44(44.0)$ & $4(4.0)$ & $20(20.0)$ & $25(25.0)$ & $7(7.0)$ & $2.5 \pm 1.4(3)$ \\
\hline
\end{tabular}




\begin{tabular}{|c|c|c|c|c|c|c|}
\hline $\begin{array}{l}\text { Blame myself for } \\
\text { not knowing what } \\
\text { to do }\end{array}$ & $5(5.0)$ & $33(33.0)$ & $18(18.0)$ & $31(31.0)$ & $13(13.0)$ & $3.1 \pm 1.2(3)$ \\
\hline $\begin{array}{l}\text { Wish that I could } \\
\text { change what had } \\
\text { happened or how I } \\
\text { felt }\end{array}$ & $8(8.0)$ & $20(20.0)$ & $13(13.0)$ & $35(35.0)$ & $24(24.0)$ & $3.5 \pm 1.3(4)$ \\
\hline $\begin{array}{l}\text { Focus on my general } \\
\text { inadequacies }\end{array}$ & $0(0.0)$ & $1(1.0)$ & $16(16.0)$ & $36(36.0)$ & $47(47.0)$ & $4.3 \pm 0.8(4)$ \\
\hline Total & & & & & & $22.8 \pm 4.6$ \\
\hline \multicolumn{7}{|l|}{ Avoidance coping } \\
\hline $\begin{array}{l}\text { Take some time off } \\
\text { and get away from } \\
\text { the situation }\end{array}$ & $31(31.0)$ & $25(25.0)$ & $19(19.0)$ & $22(22.0)$ & $3(3.0)$ & $2.4 \pm 1.2(2)$ \\
\hline $\begin{array}{l}\text { Treat myself to a } \\
\text { favorite food or } \\
\text { snack }\end{array}$ & $8(8.0)$ & $32(32.0)$ & $22(22.0)$ & $22(22.0)$ & $16(16.0)$ & $3.1 \pm 1.2(3)$ \\
\hline Visit a friend & $0(0.0)$ & $15(15.0)$ & $47(47.0)$ & $30(30.0)$ & $8(8.0)$ & $3.3 \pm 0.8(3)$ \\
\hline Buy myself something & $0(0.0)$ & $27(27.0)$ & $45(45.0)$ & $19(19.0)$ & $9(9.0)$ & $3.1 \pm 0.9(3)$ \\
\hline $\begin{array}{l}\text { Spend time with a } \\
\text { special person }\end{array}$ & $0(0.0)$ & $14(14.0)$ & $45(45.0)$ & $29(29.0)$ & $12(12.0)$ & $3.4 \pm 0.9(3)$ \\
\hline $\begin{array}{l}\text { Go out for a snack } \\
\text { or meal }\end{array}$ & $7(7.0)$ & $42(42.0)$ & $19(19.0)$ & $19(19.0)$ & $13(13.0)$ & $2.9 \pm 1.2(3)$ \\
\hline Phone a friend & $0(0.0)$ & $12(12.0)$ & $33(33.0)$ & $15(15.0)$ & $40(40.0)$ & $3.8 \pm 1.1(4)$ \\
\hline Total & & & & & & $22 \pm 4.5(21)$ \\
\hline
\end{tabular}

Table (3) : shows that the task-oriented coping had the highest mean and median scores $[26.5 \pm 2.9$ (26)] followed by the emotion-oriented coping [22.8 \pm 4.6 (23)] and lastly avoidance coping [22 $\pm 4.5(21)]$. 


\section{Discussion}

Police work has been identified as the most psychologically stressful and critical profession in the world (Bonifacio, 1991). Individuals in highrisk professions, particularly "those who fulfill a helping role during or after traumatic events", have been labeled as being involved in critical occupations (Paton and Smith, 1996). Due to the inherent nature of police work, this profession is likely to be one of the most stressful occupations in the world (Selye, 1980).

This study revealed high stress level among police officers with a mean overall stress index (133.7) ( Table 1). This is intermediate to the previous findings. A lower overall stress index mean score of 121.68 was reported in Police Constables of Police Departments in India (Hunnur et al., 2014a). However, another Indian study of 50 Police Sub- Inspectors / Asst. Sub-Inspectors in Police Departments reported an overall stress index mean score was 175.54 (Hunnur et al., 2014b). These differences in the overall mean OSI could be attributed to differences in job responsibilities and socio-cultural background of the studied police officers.

In this study it is possible that OSI may be overestimated as the participants are the attendants of social club who could represent the stressed officers seeking coping through social activities. However, the possibility of underestimated OSI cannot be ruled out. It is possible that the participants are those with free time, less duties and stress, and they enjoy their social life.

Previous studies explained this high level of stress to negative working environment abundance; long working hours, lack of time for family, irregular eating habits, need to take tough decisions, sleepless nights, poor living conditions, torture by seniors and the dwindling public confidence in the police force. It may occur also due to organizational factors like management style, poor communication, lack of support, inadequate resources and work overload, inadequate leaves, political pressures, frequent transfer, negative public image, and exposure to duty related traumatic events (Collins and 
Gibbs, 2003; Deb et al., 2008; Arial et al., 2010; Bano, 2011). All these sources of work stress are expected to be frequent among Egyptian police officers specially after the revolutions (2011 \& 2013).

Our study showed that, among the minimum scores, powerlessness, low status, and unprofitability scored least (3) and the highest score was (16) for role overload. Among maximum scores, the highest score of (27) was for role overload and the least score of (10) was for unprofitability. The average score was highest for role overload and the least was for low status with mean (6.2) (Table 1). Similarly, the study of Police Constables in Police Departments in India, observed that among the minimum scores, powerlessness scored least followed by low status scoring 1. The highest score was 8 for role overload. Among maximum scores, the least score of 5 was for powerlessness and the highest score was 25 is for role overload. The average score was highest for role overload 18.49 and the least was for powerlessness with a mean 3.41 (Hunnur et al., 2014a). However the Indian study of Police
Sub- Inspectors / Asst. Sub-Inspectors in Police Departments revealed that among the minimum scores, unprofitability scored least followed by low status scoring with 2 . The highest score was 15 for role overload. When the maximum scores are compared, the least score of 10 was for unprofitability and the highest score of 28 was for role overload. The average score was highest for role overload 22.40 and the least was for unprofitability with mean 7.12 (Hunnur et al., 2014b).

A recent Indian study included 300 male police personnel (100 constables, 100 inspectors and 100 officers) revealed statistically significant highest level of overall stress among inspectors followed by officers and constables. Officers had the highest stress in the domains of management of people and role ambiguity. Moreover, the qualitative analysis had revealed that they were also highly stressed up in the areas of overload, organizational structure and role conflict. Qualitative analysis had also shown that $90 \%$ of the officers felt stressed up due to high levels of accountability and political interference, $80 \%$ of them were stressed 
due to long and odd work hours, frequent transfers and postings, $70 \%$ of them due to change in priorities, due to political shakiness, difficulty in sanctioning of leaves, role conflict between "being family person" versus "police person," adjusting with seniors and not being able to spend time with their family (Singh and Kar, 2015).

Our results present in Table 2 were similar to that of the study of 118 police officers from 19 police districts in Kerala, India where stress was significantly more among officers who are younger $(<40 \mathrm{yrs}$.), more educated (preferably graduate and above), posted in urban areas and less experienced ( $<10$ years). Living with family, post and marital status of police officers have no significant impact on stress level of police officers (Joseph and Nagarajamurthy, 2014).

Also, in the comparison of two subsamples of 519 male policemen in France, first with a high stress level and second with a low or moderate stress level, it was found that subjects in the first group were older (between 30 and 50 year old) and more frequently divorced than those in the second. The stress level was linked to length of service (over 15 years), no leisure time, physical activities and no hobbies (Deschamps et al., 2003).

In contrast, the result of a study conducted upon 153 randomly selected police officers from the Ekiti State Police Command in Nigeria showed that, senior police officers do not experience more job stress than the junior ones. They suggested that status on the job has no significant effect on the stress experienced by both the senior and junior police officers. Their plausible explanation of this was that every job activities have its attached stressors, which the workers performing that work activities will have to experience. These job stressors are present in all work activities (Omolayo, 2012).

Our study showed that, the taskoriented coping had the highest mean and median scores followed by the emotion-oriented coping and lastly avoidance coping (Table 3). In accordance with this result, Evans et al. (1993) showed that police officers tend to use more problem-focused coping 
strategies (aimed at changing stressful occupational events), and less emotionfocused coping strategies (aimed at regulating their distress). Violanti (1992) found that the use of emotionfocused coping strategies result in higher levels of psychological distress, while the use of problem-focused coping strategies resulted in lower levels of psychological distress. Police officers probably compound stress by avoiding emotion-focused strategies, and when using such strategies, it only acts to exacerbate psychological stress, because the expression of emotion is not allowed in the policing environment (Stephens and Long, 2000; Kop and Euwema, 2001).

\section{Study Limitations}

This study suffers some limitations. As the study was carried out on a small sample not representative to all police officers, its results cannot be generalized. There was no baseline or periodic mental and medical assessment of police officers for early detection of signs and symptoms of job stress and its health consequences that could affect their work satisfaction and performance to be managed properly.

\section{Conclusion and recommendations}

Since policing is generally perceived as highly and increasingly stressful occupation as being trapped between the increasing threat of violence on our streets especially after revolution and high public demand on police efficiency and honesty, therefore attention should be paid to stress management of police personnel. This could be achieved by regular organization of training programs and counseling to increase self-efficacy and coping skills, changes should be made within the police department to prevent stress and its effects and finally treatment of stressrelated medical problems. The police organization itself can also introduce steps to improve their public image. There is a need of a nation-wide multicenter study covering all sectors of Ministry of Interior to explore the actual magnitude of job stress and its associated work-related factors. The most common method for preventing stress is to train officers to recognize its signs and sources and to develop individual coping strategies and use stress reduction techniques and services.

\section{Conflict of interest}

None. 


\section{References}

1. Arial M, Gonik V, Wild P and Danuser B (2010): Association of work related chronic stressors and psychiatric symptoms in a Swiss sample of police officers; a cross sectional questionnaire study. Int Arch Occup Environ Health; 83(3): 323-31.

2. Bano B (2011): Job Stress among Police Personnel. International Conference on Economics and Finance Research IPEDR, vol.4.

3. Bonifacio P (1991): The psychological effects of police work: A psychodynamic approach. London: Plenum Press.

4. Collins PA and Gibbs AC (2003): Stress in police officers: a study of the origins, prevalence and severity of stress-related symptoms within a country police force. Occup Med (Lond); 53(4): 256-64.

5. Czaja-Miturai I, Merecz-Kot D, Szymczak W and Bortkiewicz A (2013): Cardiovascular risk factors and life and occupational stress among policemen. Med Pr; 64(3): 335-48.

6. Deb S, Chakraborthy T, Chatterjee $\mathrm{P}$ and Srivastava N (2008): Job-related stress, causal factors and coping strategies of traffic constables. J Indian Acad Appl Psychol; 34: 19-28.

7. Deschamps F, Paganon-Badinier I, Marchand AC and Merle C (2003): Sources and assessment of occupational stress in the police. J Occup Health.; 45(6): 358-64.

8. Endler NS and Parker DA (1999): Coping Inventory for Stressful Situations (CISS): Manual (2nd ed.). Toronto: Multi Health Systems.

9. Evans BJ, Coman G, Stanley RO and Burrows GD (1993): Police officers' coping strategies: An Australian police survey. Stress Medicine; 9: 237-46.

10. Hunnur RR, Bagali $M M$ and Sudarshan $S$ (2014a): Workplace Stress - Causes of Work Place Stress in Police Department: A Proposal for Stress Free Workplace. IOSR Journal of Business and Management; 16(3): 39-47.
11. Hunnur RR, Bagali $M M$ and Sudarshan $S$ (2014b): Cause and Effect of Workplace Stress among Police Personnel: An Empirical Study. Int J Mgmt Res \& Bus Strat; 3(1).

12. Joseph JK and Nagarajamurthy B (2014): Stress in Police officers. IOSR Journal of Humanities and Social Science; 19(10): 39-40.

13. Kivimäki $M$, Virtanen $M$, Elovainio $M$, Kouvonen $\mathrm{A}$, Väänänen $\mathrm{A}$ and Vahtera $\mathrm{J}$ (2006): Work Stress in the etiology of coronary heart disease: a meta-analysis. Scand J Work Environ Health; 32(6): 431-42.

14. Kop N and Euwema MC (2001): Occupational stress and the use of force by Dutch police officers. Criminal Justice and Behavior; 28: 631-52.

15. Mathur P (1999): Stress in Police in India: Recognition, diagnosis and coping strategies. New Delhi: Gyan Publishing House.

16. Matthews KA, Zhu S, Tucker DC and Whooley MA (2006): Blood Pressure Reactivity to Psychological Stress and Coronary Calcification in the Coronary Artery Risk Development in Young Adults Study. Hypertension; 47(3): 3915.

17. Omolayo B (2012): Effect of Gender and Status on Job Stress among Police Officers in Ekti State of Nigeria. Bangladesh e-Journal of Sociology; 9(1).

18. Paton D and Smith LM (1996): Psychological trauma in critical occupations: Methodological and assessment strategies, In Paton, D. \& Violant, J.M. (Eds.), Traumatic stress in critical occupations: Recognition, consequences and treatment, Illinois, USA: Thomas Books.

19. Ramachandruni S, Handberg E and Sheps DS (2004): Acute and chronic psychological stress in coronary disease. Curr Opin Cardiol; 19(5): 494-9.

20. Ranta RS (2009): Management of Stress and Coping Behaviour of Police Personnel through Indian Psychological Techniques. J Indian Acad Appl Psychol.; 35(1): 47-53.

21. Selye H (1980): The stress concept today, In Kutash, IL \& Schlesinger, L.B., and Associates (Eds.), Handbook of stress and anxiety. San 
Francisco: Jossey-Bass cited in Sundaram MS and Kumaran MJ (2012): A Study on Occupational stress and Coping strategies among Police Head Constables (Grade III). Res J Management Sci; 1(1): 44-47.

22. Singh S and Kar SK (2015): Sources of occupational stress in the police personnel of North India: An exploratory study. Indian J Occup Environ Med; 19(1): 56-60.

23. Srivastava AK and Singh AP (1981): Construction and standardization of an occupational stress index: A pilot study. Indian Journal of Clinical Psychology; 8(2): 133-6.

24. Stephens C and Long N (2000): Communication with police supervisors and peers as a buffer to work-related traumatic stress. J Organiz Behav; 21: 407-24.
25. Violanti JM (1992): Coping strategies among police recruits in a high-stress training environment. J Soc Psychol.; 132(6): 717-29.

26. Violanti JM, Burchfiel CM, Miller DB, Andrew ME, Dorn J, Wactawski-Wende J, Beighley CM, Pierino K, Joseph PN, Vena JE, Sharp DS and Trevisan M (2006): The Buffalo Cardio-Metabolic Occupational Police Stress (BCOPS) pilot study methods and participant characteristics. Ann Epidemiol; 16(2): 148-56.

27. Wang HX, Leineweber C, Kirkeeide R, Svane $\mathrm{B}$, Schenck-Gustafsson $\mathrm{K}$, Theorell $\mathrm{T}$ and Orth-Gomér K (2007): Psychosocial stress and atherosclerosis: Family and work stress accelerate progression of coronary disease in women. The Stockholm Female Coronary Angiography Study. J Intern Med; 261(3): 24554. 